\title{
IAMJ
}

INTERNATIONAL

AYURVEDIC

MEDICAL JOURNAL

\section{A CRITICAL EVALUATION OF KADALI KANDA (Musa paradisiaca Linn.Rhizome) CHURNA AND KWATHA IN AMLAPITTA}

\author{
Veeresh S. $\mathbf{M}^{1}$, Mohan Kumari K. $\mathbf{M}^{2}$ \\ ${ }^{1}$ M D (Dravya Guna), Consultant, OM Ayurveda and Yoga Health Centre, Mysuru, Karnataka, India. \\ ${ }^{2}$ M.S (Shalakya Tantra), Associate Professor, Depatment of Shalakya Tantra, G.A.M.C, Mysuru, Karnataka, \\ India.
}

Corresponding Author: ayurveeru@gmail.com

https://doi.org/10.46607/iamj0709022021

(Published online: February 2021)

Open Access

(C) International Ayurvedic Medical Journal, India 2021

Article Received: 31/01/2021 - Peer Reviewed: 06/02/2021 - Accepted for Publication: 09/021/2021

(D) Check for updates

\begin{abstract}
Amlapitta is one of the Annavahasroto vikara (gastrointestinal system) described in many classical Ayurvedic texts. Modern luxurious lifestyle and sendentary habits of people have been inviting so many diseases like Prameha (Diabetis), Amavata (Arthritis), Amlapitta (Gastritis) etc. The cardinal features of Amlapitta includes utklesha (nausea), hritdaha (heartburn), kantadaha (throat burn), amlodgara (sour and bitter belching), chardi (vomiting), kukshidaha (abdominal burn) etc. The present study was taken up to evaluate efficacy of Kadali kanda churna and Kadali kanda kwatha in Urdwaga Amlapitta (Functional dyspepsia). A total of 20 patients having clinical features of Urdwaga Amlapitta were selected and randomly divided into 2 groups with 10 patients each. Group A was treated with Kadali kanda churna and Group B was treated with Kadali kanda kwatha. Subjective parameters were suitably graded to assess the results based on the clinical observations. Statistical tests were applied to analyze the results. In the present study it was observed that the percentage of success of Group A was $93.75 \%$ and that of Group B was $65 \%$. Group A showed better results when compared to Group B.
\end{abstract}

Keywords: Amlapitta, Kadali kanda churna, Kadali kanda kwatha. Gastritis 


\section{INTRODUCTION}

Amlapitta is defined as 'Amlam vidagdam cha tat pittam amlapitta $^{[1]}$ and is one of the most common ailments seen all over the world. The most common upper gastrointestinal symptom seen in adults is dyspepsia. The majority of patients suffer from Functional dyspepsia or non-ulcer type, while Dyspepsia has organic causes. The prevalence of uninvestigated dyspepsia (UD) worldwide ranges from $7 \%$ to $45 \%$, depending on the definition used and the geographical area, while the prevalence of FD has been reported to range from $11 \%$ to $29.2 \%{ }^{[2]}$ The present study was taken up to treat Amlapitta with Kadali kanda churna and kwatha which are considered to be economical, safe with no side effects and above all it acts as both preventive and curative. Amlapitta, an ailment affecting the GIT, is known from Samhita period. Detailed descriptions of etiopathology, signs, symptoms, prognosis and treatment have been found in all Ayurvedic literatures. It is estimated that, nearly $25 \%$ of the populace has dyspepsia at least six times yearly,but only $10-20 \%$ present to clinicians. ${ }^{[3]}$ Patients are usually young $(<40$ yrs.) and women are affected twice as common as men ${ }^{[4]}$. Etymologically the word " $\mathrm{Am}$ lapitta" comprises of two components 'Amla' and 'Pitta ${ }^{\text {[5] }}$. Chakrapanidatta in his commentary on Charaka Samhita defines Amlapitta as 'Amlapittam cheti amlagunoudriktam pittam. Here amla guna of pitta is increased and hence called as Amlapitta ${ }^{[6]}$. In this condition the amla guna of pitta is augmented and its functions are altered. This results in Shukta paka and production of ama. ${ }^{[7]}$ This condition exhibits typical clinical presentation known as Amlapitta. The similar symptom complex of Amlapitta is considered as Functional dyspepsia in modern medicine. ${ }^{[8]}$ The term Functional dyspepsia refers to a condition where a symptomatic individual is not found to have an ulcer or other structural diseases. This condition is characterized by the presence of chronic intermittent symptoms of epigastric pain often associated with epigastric fullness, early satiety, bloating and vomiting without mucosal lesions or other structural abnormalities of the gastrointestinal tract. ${ }^{[9]}$ So the symtoms similarity is seen in Urdwaga Amlapitta and Func- tional dyspepsia. Hence in the present study Functional dyspepsia is taken as Urdwaga Amlapitta. ${ }^{[10]}$ While dealing with Shaka varga, Bhavamishra has mentioned the use of Kadali kanda in Amlapitta. ${ }^{[1]}$ Based on this reference, Kadali kanda was selected for this study to analyse its properties and action in Urdwaga Amlapitta.

\section{Aim and Objectives}

1. To evaluate the effect of Kadali kanda churna and Kwatha in the management of Amlapitta.

2. To compare the efficacy of Kadali kanda in two different pharmaceutical forms in Amlapitta.

\section{Materials and Methods}

1. A total of 20 patients having the clinical features of Urdwaga Amlapitta were selected for the study.

2. A total of 20 patients of either sex fulfilling the diagnostic criteria attending the OPD and IPD of S.D.M Ayurveda Hospital, Udupi were selected.

\section{Inclusive Criteria:}

1) Patients with pratyatma lakshana of Urdhvaga Amlapitta - Avipaka, Klama, Utklesha, Amlodgara, Gourava, Hritdaha, Kantadaha, Aruchi, Chardi, Kukshidaha, Shirashoola, Hastadaha, Padadaha, Hrillasa and Agnimandhya.

2) Patients between 15 years to 60 years.

3) A minimum history of 3 months.

\section{Exclusive Criteria:}

1) Patients below 15 years and above 60 years.

2) Patients with Adhoga Amlapitta, Parinama shoola, Annadrava shoola, Arbudha \& Grahani.

\section{Investigation:}

All the patients in the study were subjected to the following laboratory investigations as a routine measure.

1) Blood - TC, DC, ESR, $\mathrm{Hb} \%$

2) Routine urine analysis

3) If needed to confirm the diagnosis endoscopy was carried out.

Study Design: It is single blind comparative clinical study.20 patients fulfilling inclusive criteria were selected and randomly allocated into Group $\mathrm{A}$ and Group B of 10 patients each. 


\section{Intervention}

Group A-Kadali kanda choorna 3gms, three times a day was administered orally with water.

Group B- Kadali kanda Kwatha $40 \mathrm{ml}$ two times a day was administered orally. The patients of group B were properly educated to prepare kwatha from the kwatha choorna.

\section{Specific Time of Administration}

Patients of both the group were suggested to take the medicine in mid-way through their food i.e. in the mid of breakfast, in the mid of the lunch and in mid of the dinner.

\section{Duration of Treatment}

To see the efficacy of the drug the present study incorporates a minimum of 21 days medication.To confirm the result and to check for recurrence, patients were followed-up with observation once in 15 days up to 1 month, after the end of 21-day medication. During these periods patients of both the groups were strictly advised diet.

\section{Assessment Criteria:}

For subjective parameters each symptom has been graded or scored with following rating method.

$\begin{array}{lll}\text { Normal } & - & 0 \\ \text { Mild } & - & 1 \\ \text { Moderate } & - & 2 \\ \text { Severe } & - & 3\end{array}$

The patients with mild amlapitta are defined as those with one or more of the following.

1) Symptoms occur less than 2 times in a week are due to exposed to risk factor.

2) Presence of symptoms for few hours does not interfere with work performance; occasionally feel inconvenience during routine work.

3) Nausea may be present, but vomiting is rare.

The patient with moderate amlapitta is defined as those with one or more of the following.

1) Presence of symptoms 2 to 4 times in a week.
2) The symptoms present during day and night has interference but doesn't prohibit work performance and other activities.

3) Occasional presence of vomiting

The patients with severe amlapitta are defined as those with one or more of the following.

1) Continuous presence of symptoms.

2) Symptoms develop during the day as well as in the night hrs.

3) Frequent vomiting.

Follow Up Study

After the completion of treatment for 21 days, patients were advised to attend OPD every 15

days for one month at regular intervals.

Drug Used

Kadali kanda

Scientific name: Musa paradisiaca

Nomenclature: Banana

Parts used: Rhizome

Collection of Drug

The fresh rhizome of Musa paradisica Linn was collected in required quantity from the local vicinity at Udupi.

Method of Preparation. ${ }^{[12]}$

Musa paradisiaca rhizome was processed and packed in S.D.M. Ayurveda Pharmacy in the following way.

The fresh rhizome after collection was washed properly to remove mud and other physical impurities. The outer blackish or dark greyish peal was scraped and removed. The cleaned cream coloured rhizome was made into small pieces and dried in dryer at $60^{\circ} \mathrm{C}$. Completely dried pieces were made into sookshma choorna and kwatha choorna separately. The 200 gms, sookshma choorna was filled in plastic covers and then sealed. The 400 gms, kwatha choorna was also filled in plastic covers, sealed and labeled properly. The plastic packet were kept within airtight plastic containers and stored in cool dry place. Thus, the trial medicine was prepared. 

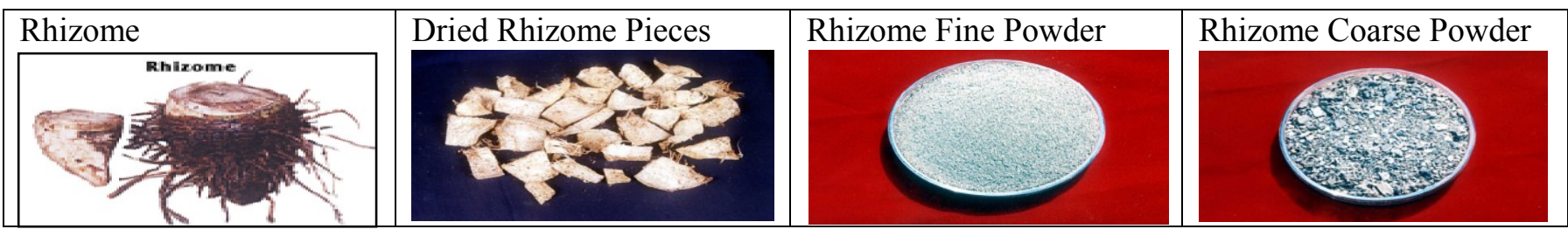

\section{Determination of Heavy Metals:}

The ash of the Banana rhizome powder was subjecte to following heavy metal detection through Inductively Coupled Mass Spectrophotometry ${ }^{[13]}$ and the results obtained were mentioned.

Table 1: Result of Heavy Metals Detection

\begin{tabular}{|c|c|}
\hline Parameter & Results (in ppm) \\
\hline Arsenic & $<0.1$ \\
\hline Cadmium & $<0.1$ \\
\hline Copper & 2.9 \\
\hline
\end{tabular}

\begin{tabular}{|c|c|}
\hline Iron & 267.3 \\
\hline Mercury & $<0.1$ \\
\hline Lead & 1.1 \\
\hline Zinc & 7.5 \\
\hline
\end{tabular}

\section{RESULTS}

Total 20 Patients were registered for the study and they were randomly distributed in 2 groups as Group A \& Group B consisiting of 10 patiens each. Results of each Group and comparitive results of both Groups were analysed by using Paired $t$ test.

Table 2: Effect of Treatment on Clinical Features of Urdhvaga Amlapitta in Group A

\begin{tabular}{|l|l|l|l|l|l|}
\hline SI No & Lakshanas & $\begin{array}{l}\text { No } \\
\text { of Patients }\end{array}$ & Before Treatment & $\begin{array}{l}\text { After } \\
\text { Treatment }\end{array}$ & $\begin{array}{l}\text { After Treatment } \\
\text { (In Percentage) }\end{array}$ \\
\hline 01 & Avipaka & 3 & 0.300 & 0.100 & 66.66 \\
\hline 02 & Klama & 4 & 0.400 & 0.000 & 100 \\
\hline 03 & Utklesha & 10 & 2.000 & 0.000 & 100 \\
\hline 04 & Amlodgara & 10 & 2.100 & 0.200 & 90.48 \\
\hline 05 & Gourava & 2 & 0.200 & 0.000 & 100 \\
\hline 06 & Hritdaha & 10 & 2.300 & 0.200 & 91.30 \\
\hline 07 & Kantadaha & 10 & 2.000 & 0.200 & 90 \\
\hline 08 & Aruchi & 2 & 0.200 & 0.100 & 50 \\
\hline 09 & Chardi & 10 & 1.700 & 0 & 100 \\
\hline 10 & Kukshidaha & 10 & 1.600 & 0.100 & 93.75 \\
\hline 11 & Shirashoola & 3 & 0.300 & 0.100 & 66.66 \\
\hline 12 & Hastadaha & 3 & 0.300 & 0.000 & 100 \\
\hline 13 & Padadaha & 3 & 0.300 & 0.000 & 100 \\
\hline 14 & Hrillasa & 3 & 0.400 & 0.000 & 100 \\
\hline 15 & Agnimandhya & 4 & 0.400 & 0.000 & 100 \\
\hline
\end{tabular}

In-Group-A maximum relief was observed in Klama, Utklesha, Vanti, Hastadaha, Padadaha, Jwara, Hrillasa, Agnimandya, Mukalepa, Nidradhikya (100\%), Kukshidaha (93.75\%), Hritdaha (91.30\%), Amlodgara and Kantadaha $(90.48 \%)$ after the course of treatment.

Table 3: Effect of Treatment on Urdhvaga Amlapitta in Group B

\begin{tabular}{|l|l|l|l|l|l|}
\hline SI. No. & Lakshanas & $\begin{array}{l}\text { No } \\
\text { of Patients }\end{array}$ & Before Treatment & After Treatment & $\begin{array}{l}\text { After Treatment } \\
\text { (In Percentage) }\end{array}$ \\
\hline 01. & Avipaka & 4 & 0.400 & 0.100 & 75 \\
\hline 02. & Klama & 4 & 0.400 & 0.000 & 100 \\
\hline
\end{tabular}




\begin{tabular}{|l|l|l|l|l|l|}
\hline 03. & Utklesha & 10 & 2.200 & 0.600 & 72.72 \\
\hline 04. & Amlodgara & 10 & 2.000 & 0.700 & 65 \\
\hline 05. & Gourava & 3 & 0.300 & 0.100 & 66.66 \\
\hline 06. & Hritdaha & 10 & 2.100 & 0.400 & 80.95 \\
\hline 07. & Kantadaha & 10 & 1.500 & 0.400 & 73.33 \\
\hline 08. & Aruchi & 5 & 0.500 & 0.000 & 100 \\
\hline 09. & Chardi & 10 & 1.600 & 0.000 & 100 \\
\hline 10. & Kukshidaha & 10 & 2.000 & 0.700 & 65 \\
\hline 11. & Shirashoola & 4 & 0.400 & 0.100 & 75 \\
\hline 12. & Hastadaha & 4 & 0.400 & 0.000 & 100 \\
\hline 13. & Padadaha & 4 & 0.400 & 0.000 & 100 \\
\hline 14. & Hrillasa & 4 & 0.800 & 0.700 & 87.5 \\
\hline 15. & Agnimandhya & 5 & 0.600 & 0.100 & 83.33 \\
\hline
\end{tabular}

In Group-B maximum relief was appreciated in Klama, Aruchi, Hastadaha, Padadaha, Jwara (100\%) and Hrillasa $(87.5 \%)$ after the course of treatment

\section{Assessment of Overall Result}

The data of the two groups were compared, they were found to be statistically significant after treatment. In Group A, percentage of improvement after treatment was $93.75 \%$ and in group B improvement was $65 \%$.

Table 4: Statistical analysis of Group A and Group B

\begin{tabular}{|c|c|c|c|c|c|c|c|c|c|}
\hline \multirow[t]{2}{*}{ Group } & \multirow[t]{2}{*}{$\mathrm{N}$} & \multirow[t]{2}{*}{ BT } & \multirow[t]{2}{*}{ AT } & \multicolumn{6}{|c|}{ Paired ' $t$ ' test } \\
\hline & & & & Difference & $\%$ & SD & SEM & $\mathrm{t}$ & $\mathrm{P}$ \\
\hline \multirow[t]{2}{*}{ A } & \multirow[t]{2}{*}{10} & \multirow[t]{2}{*}{1.600} & \multirow[t]{2}{*}{0.1000} & \multirow[t]{2}{*}{1.500} & \multirow[t]{2}{*}{93.75} & \multirow[t]{2}{*}{0.527} & 0.163 & \multirow[t]{2}{*}{9.000} & \multirow[t]{2}{*}{$<0.001$} \\
\hline & & & & & & & 0.100 & & \\
\hline \multirow[t]{2}{*}{ B } & \multirow[t]{2}{*}{10} & \multirow[t]{2}{*}{2.000} & \multirow[t]{2}{*}{0.700} & \multirow[t]{2}{*}{1.300} & \multirow[t]{2}{*}{65} & \multirow[t]{2}{*}{0.823} & 0.258 & \multirow[t]{2}{*}{4.993} & \multirow[t]{2}{*}{$<0.001$} \\
\hline & & & & & & & 0.153 & & \\
\hline
\end{tabular}

\section{DISCUSSION}

Urdhvaga Amlapitta is said to be located in Amashaya that is within the upper part of the gastrointestinal tract causing gastrointestinal disturbances. By reviewing the Urdhvaga Amlapitta roga nidana it is evident that due to pitta and kaphakara nidana, pitta and kapha doshas are increased leading to the Urdhvaga Amlapitta and could be compared with Functional dyspepsia in contemporary modern medical science. Kadali kanda is one such drug mentioned in the classics for its multiple varied benefits in therapeutics. It is having kashaya, madhura, guru guna and sheeta veerya hence reduces pitta and due to its rooksha guna reduces kapya. ${ }^{[14]}$ Thus on this basis of rasa and guna the Amlapittahara action of kadali kanda could be justified.
A Clinical trial has been conducted to know the toxic heavy metals in kadali kanda it was subjected to Inductively Coupled Mass Spectrophotometry. Finally it was found that the trial drug is having within normal values of heavy metals i.e. body resistance toxic heavy metals in PPB/PPM levels.After the study of toxic heavy metals, the clinical study was conducted to evaluate the therapeutic efficacy of the trial drug in the management of patients with the established Urdhvaga Amlapitta lakshanas.

\section{Incidence of disease:}

Age-Urdhvaga Amlapitta may begin at any age mainly in middle aged adults or below 40 years of age. In this study, the same was observed that majority of the patients belong to the age group of 21-30 years with $45 \%$ \& to some extent $30-40$ years with $30 \%$. 
Occupation-This study shows that persons who are under extreme stress and strain, persons having irregular and faulty food habits were the sufferers.

Dietary habits-In this study it was observed that $90 \%$ patients were mixed diet, the reason for the disease may be due to their faulty food habits like excess intake of spicy, oily, salty and heavy food.

Aggravating factors-The majority of patients were observed to have diet and seasonal variations in relation with acute exacerabation of the disease. Food items having more pungent, sour and salt tastes and drinks like tea, coffee, alcohol etc. Viharas like akalabhojana, dhumapana and mental status like chinta, krodha etc, were commonly identified as aggravating factors.

Relieving factors- Majority of the patients were able to identify the relieving factors like regular food intake, coldmilk, and sweet foods. Also, many patients observed that vomiting voluntarily is also one of the relieving factors in Urdhvaga Aamlapitta.

\section{Overall effect of medication on the features of} Urdvaga Amlapitta.

Kadali kanda choorna is better compared to kadali kanda kwatha in the following features like Utklesha, amloudgara, gourava, hritdaha, kantadaha, kukshidaha, hrillasa, agnimandhya, mukalepa, nidradhikya. Kadali kanda kwatha is better compared to kadali kanda choorna in the following features like avipaka, aruchi and shirashoola.

Overall pictures of the results obtained in both the group suggests that Kadali kanda choorna showed better response in controlling the severity of the disease and is effective in significantly reducing most of the manifestations. In few of the features of Urdhvaga Amlapitta, kadali kanda kwatha produced better response. The trial drug had no side effects or any sort of toxic effect on the patients.

\section{CONCLUSION}

According to classical and contemporary modern literatures the trial drug kadali (Musa paradisiaca Linn Rhizome) is having much significance and importance being extensively used for its varied benefits. The drug when used in choorna form was more effective than in kwatha form and the response were very good in cases of mild and moderate severity. The trial drug is free from any sort of side effects or toxic effects in its therapeutic dose and hence it is found to be a safe remedy. The drug is having all the actions on Amlapitta (Urdhvaga) mentioned by the classics namely dahaprashamana and agnideepana, which was observed during clinical study. The drug is rich in fibre and starch; it relieved constipation when administered in choorna form. In kwatha form there was comparatively poor effect in relieving constipation. The presence of high percentage of iron may be useful in the Iron Deficiency Anaemia. Further studies can be carried out in this subject.

\section{REFERENCES}

1. AjayKumar Sharma, Kayachikitsa-II, Chaukhambha Orientalia, Varanasi- 2019, Chapter-25, Pg-326

2. Mahadeva S, Goh KL. Epidemiology of functional dyspepsia: a global perspective. World journal of gastroenterology: WJG. 2006 May 7; 12(17):2661.

3. Jameson, Fauci et al., Harrison's Princples of Internal Medicine, Mc Graw Hill Education publication, Volume-1, Edition-20th, Chapter-41, Pg-257.

4. Stuart H. Ralston, Ian D. Penman et al, Davidson's Principles and Practice of Medicine, Elsevier publications-2018, Edition-23 ${ }^{\text {rd }}$, Chapter-21 ,Pg-208.

5. Vaidya Jadavji Trikamji Acharya, Ayurveda Deepika Commentry of Chakrapanidatta on CharakaSamhita of Agnivesha, Chaukamba Orientalia, Varnasi, Reprint2015 Chikitsasthana, Grahani Chikitsa, chapter-15, Verse-47, Pg-17.

6. Madhavakara, Madhava Nidana, Madhu Kosha Vyakya by Sri Vijayarakshita and Atanka darpana Vyakya by Sri Vachaspati Vaidya, Edited by Vaidya Jadavji Tricumji Acharya, Chaukamba Orientalia, Varanasi,2017, chapter-51, verse-1, Pg-291.

7. Vridda Jivaka, Kashyapa Samhita, Vidyotini Hindi Commentry, Shri Satyapala Bhishagacharya, $10^{\text {th }}$ edition, Chaukhambha Sanskrit sansthana, Varanasi, 2005, Uttarakhanda, Chapter-16, Verse-9, Pg-336.

8. Madhavakara, Madhava Nidhana Chapter 51, Amlapitta nidanam adyaya. E Samhita http://niimh.nic.in/ebooks/madhavanidana/?mod=read

9. H. Winter Grippith, Mark R. Dambro, The Five Minute Clinical Assissment, United States of America, 1994, Pg-344. 
10. Brahmananda Tripati, Madhukosha Commentry of Madhava nidhana of Madhavakara, Amlapitta Nidanam, Chaukhamba Surbharati Prakashan, Varnasi, Chapter-51, Verse-4, 5, 6, Pg-227.

11. Dr Bulusu Sitaram, Bhavaprakasha of Bhavamishra, Poorvakhanda, Prathama bhaga, Mishraka prakarana, Chaukambha Orientalia, Varanasi, Reprint edition2018, Shaka varga, Chapter-6, Verse-105, Pg-470.

12. Agnivesha, Charaka Samhita, sutra sthana, Chapter 04, Shadvirechanashashritiya adyaya. E Samhita http://niimh.nic.in/ebooks/ecaraka/?mod=

13. https://www.ncbi.nlm.nih.gov/pmc/articles/PMC67197 45/_(cited on 08/02/2021 at $08.25 \mathrm{pm}$ )

14. Vagbhata Astanga hrudaya Sutrasthana Chapter 1/18 available at

15. E Samhita - http://ayurvidya.net/shastra/hridayam/

\section{Source of Support: Nil \\ Conflict of Interest: None Declared}

How to cite this URL: Veeresh S. M. \& Mohan Kumari K. M: A Critical Evaluation Of Kadali Kanda (Musa Paradisiaca Linn. Rhizome) Churna And Kwatha In Amlapitta. International Ayurvedic Medical Journal \{online\} 2021 \{cited February, 2021\} Available from: http://www.iamj.in/posts/images/upload/367 373.pdf 